\title{
Recent Change-_River Run-off and Ice Cover
}

\author{
Jukka Käyhkö, Elga Apsite, Anna Bolek, Nikolai Filatov, \\ Sergey Kondratyev, Johanna Korhonen, Jurate Kriaučiūnienè, \\ Göran Lindström, Larisa Nazarova, Anna Pyrh, \\ and Marzenna Sztobryn
}

\begin{abstract}
This chapter compiles and assesses information on run-off and discharge from rivers within the Baltic Sea drainage basin. Some information is also available on ice duration on inland waterways. Although decadal and regional variability is large, no significant long-term change has been detected in total river run-off to the Baltic Sea over the past 500 years. A change in the timing of the spring flood has been observed due to changes in the timing of snowmelt. Change in temperature seems to explain change in run-off better than does precipitation. Later start dates for ice formation on waterways, and earlier ice break-up dates have resulted in shorter periods of ice cover.
\end{abstract}

\section{Keywords}

Baltic sea $\bullet$ Climate change $\cdot$ River $\bullet$ Run-off $\bullet$ Discharge $\bullet$ Ice cover

J. Käyhkö (ه)

Department of Geography, University of Turku, Turku, Finland e-mail: jukkay@utu.fi

\section{E. Apsite}

Faculty of Geographical and Earth Sciences, University of Latvia, Riga, Latvia

\section{A. Bolek}

Institute of Meteorology and Water Management, Warsaw, Poland

N. Filatov $\cdot$ L. Nazarova

Laboratory of Geography and Hydrology, Northern Water

Problems Institute, Petrozadovsk, Russia

\section{S. Kondratyev}

Institute of Limnology, Russian Academy of Sciences,

St. Petersburg, Russia

J. Korhonen

Freshwater Centre, Finnish Environment Institute, Helsinki,

Finland

J. Kriaučiūnienè

Laboratory of Hydrology, Lithuanian Energy Institute, Kaunas,

Lithuania

\section{G. Lindström}

Research and Development, Swedish Meteorological and

Hydrological Institute, Norrköping, Sweden

A. Pyrh

Hydrology Department, Estonian Environment Agency, Tallinn, Estonia

M. Sztobryn

Hydrological Forecast Office, Institute of Meteorology and Water

Management, Gdynia, Poland

\section{$5.1 \quad$ Introduction}

This chapter compiles and assesses recent information on run-off and river discharge ${ }^{1}$ within the Baltic Sea basin. Most of the information is based on peer-reviewed scientific publications, but a substantial share of the data has been provided by national authorities responsible for hydrological monitoring. Lake hydrology is not addressed in this chapter because widespread regulation for hydropower generation and the resulting complexity in lake level variation tend to hamper attempts to assess climatically induced change. Readers interested in the impact of climate change specifically on lakes are advised to refer to the European-scale review by Glen (2010).

\footnotetext{
${ }^{1}$ In this chapter, the terms inflow, runoff and discharge are used as follows. Runoff describes general, long-term and/or regional processes and is typically given as litres per second per square kilometre $\left(1 \mathrm{~s}^{-1} \mathrm{~km}^{-2}\right.$ ) (allowing comparisons between rivers of different sizes) or millimetres per year $\left(\mathrm{mm} \mathrm{year}^{-1}\right)$ (allowing comparisons with precipitation and evaporation), whereas inflow and discharge typically refer to immediate channel flow and are given as cubic metres per second $\left(\mathrm{m}^{3} \mathrm{~s}^{-1}\right)$. Where possible, the terminology used in the original publications has been respected.
} 
The magnitude of water flow in a river is the result of various complex hydrological processes including precipitation, evapotranspiration, infiltration and storage (in the form of snow, soil moisture, and sub-surface and groundwater storage, etc.). Explaining changes in streamflow thus requires an understanding of these parameters of which precipitation is often pivotal. Meteorological parameters are addressed in Chap. 4, but some notes may be beneficial for general reference. Bordi et al. (2009) studied linear and nonlinear trends in drought and wetness within Europe in terms of the gridded standardised precipitation index (SPI) determined from monthly precipitation reanalyses by the National Centers for Environmental Prediction/National Center for Atmospheric Research (NCEP/NCAR). They concluded that time series of drought and wetness area coverage show a marked linear trend until about the end of the twentieth century at which point the trends reverse. The recent reversed nonlinear trend is particularly pronounced on the hydrological timescale. Substantial regional variation occurs in drought/wetness trends (Fig. 5.1).

Another European-wide example is provided by Stahl et al. (2010) who studied streamflow trends in 1962-2004 in a broad European study consisting of 411 near-natural small catchments in 15 countries. Positive trends with increasing streamflow were found in the winter months in most catchments, while in spring and summer months, strong negative trends (decreasing streamflow, shift towards drier conditions) were found specifically in the southern and eastern regions of the study area, as well as widespread across Europe. A marked shift towards negative trends was observed in April, gradually spreading across Europe to reach a maximum extent in August. Low flows have decreased in most regions where the lowest mean monthly flow occurs in summer, but vary for catchments which have flow minima in winter and secondary low flows in summer. The study by Stahl et al. (2010) largely confirmed findings from national- and regional-scale trend analyses.
Fig. 5.1 Spatial distribution of the tendency towards wetter and drier conditions within Europe including the Baltic Sea basin. This is shown by plots of the angular coefficient $p 1$ (in year ${ }^{-1}$ ) of the linear trend fitting the SPI24 time series for the two time sections: a December 1949 to February 2009 and b December 1949 to December 1997. Negative (blue) values of $p 1$ denote a tendency towards drier periods, while positive ( $r e d$ ) ones towards wetter periods (Bordi et al. 2009)
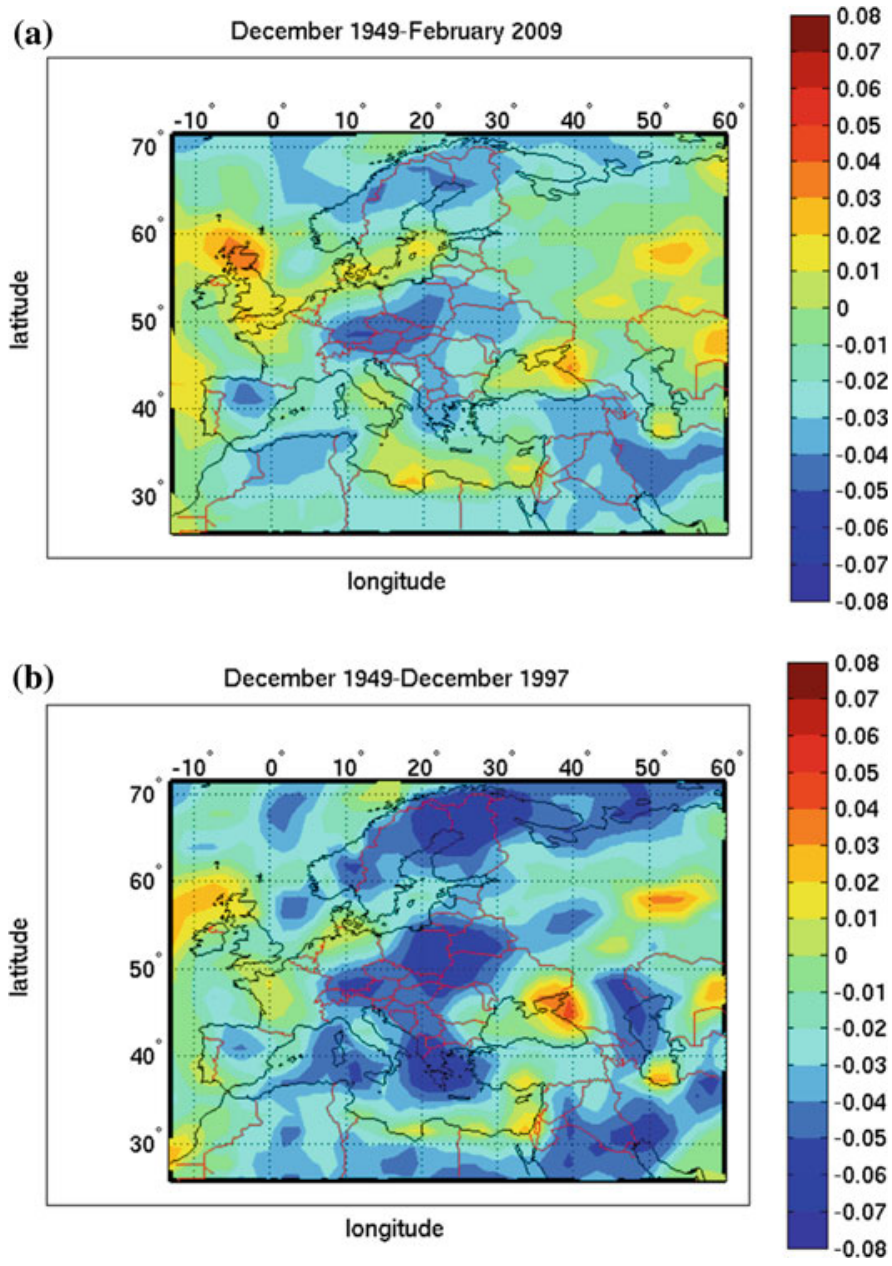


\subsubsection{General Drainage Characteristics of the Baltic Sea Basin}

The land surface of the Baltic Sea basin, in other words the drainage area of the Baltic Sea, covers 1.74 million $\mathrm{km}^{2}$. It includes the territories of 14 countries. Three countries-Estonia, Latvia and Lithuania - are located entirely within the Baltic Sea basin, while only minor parts of the following countries drain towards the Baltic Sea: Czech Republic, Germany, Norway, Slovakia and Ukraine. The largest national areas of the Baltic Sea basin are those of Sweden (25.3\%), Russia (19.0\%), Poland (17.8\%) and Finland (17.4\%). These four countries together cover two-thirds of the basin.

The exact number of sub-basins within the Baltic Sea catchment area is a matter of definition, but Hannerz and Destouni (2006) have delineated 634 river basins of more than $6 \mathrm{~km}^{2}$ in area (Fig. 5.2). The ten largest river basins draining into the Baltic Sea and some of their characteristics are summarised in Table 5.1. The ten rivers account for $58 \%$ of the Baltic Sea catchment area and $55 \%$ of inflow. The 11-20th ranked basins have a total area of $251,000 \mathrm{~km}^{2}$ (14\% of the total) while the hundred largest basins cover about $86 \%$ of the Baltic Sea catchment. The remaining $14 \%$ (representing a quarter of a million square kilometres) are divided into numerous small catchments along the coastal regions and on the Baltic Sea islands. The total area of the Baltic Sea islands is almost $40,000 \mathrm{~km}^{2}$, and there are around 200,000 islands in total.

Although there is some overlap, the ten largest river basins are not the top ten in terms of mean annual flow. The specific run-off is greatest in the north-western parts of the Baltic Sea catchment; three rivers from that regionÅngermanälven, Luleälven and Indalsälven - cover positions $8-10$, displacing the Narva, Torne and Kymi rivers.

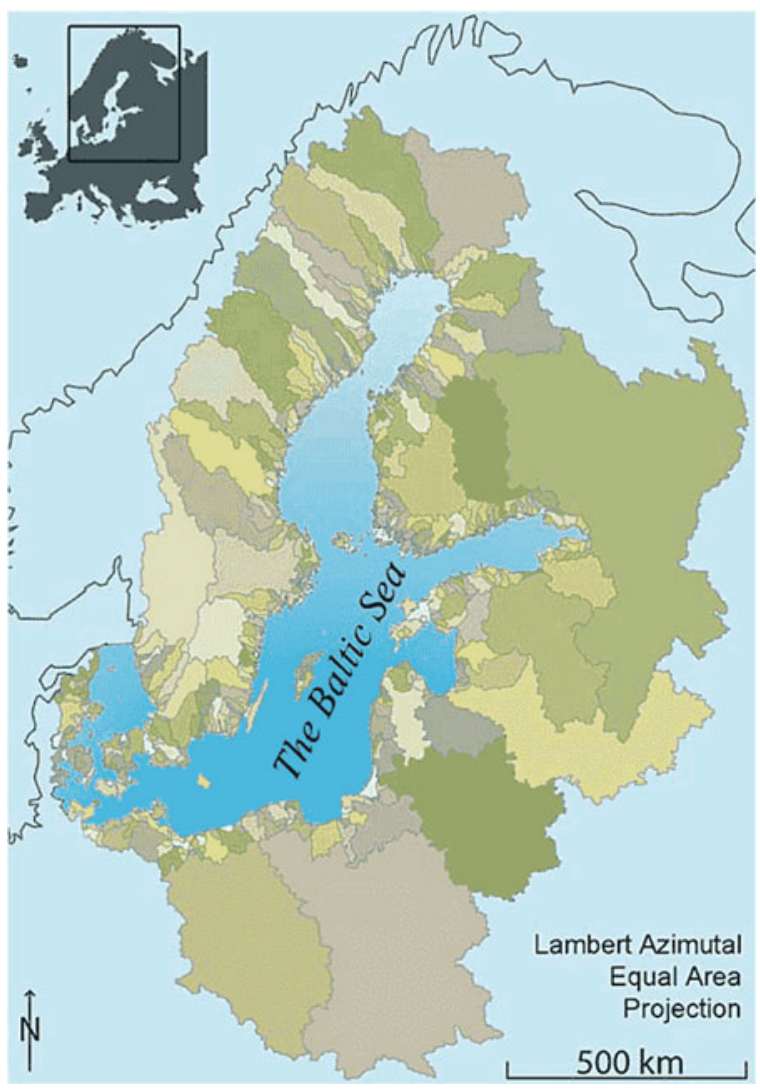

Fig. 5.2 Sub-basins of the Baltic Sea drainage basin greater than $6 \mathrm{~km}^{2}$ in size (Hannerz and Destouni 2006)

The drainage area of Lule River is only $25,200 \mathrm{~km}^{2}$ but the run-off, $19.01 \mathrm{~km}^{-2} \mathrm{~s}^{-1}$, leads to a mean annual discharge of $486 \mathrm{~m}^{3} \mathrm{~s}^{-1}$.

The first assessment of climate change in the Baltic Sea basin (BACC Author Team 2008) summarised the scientific

Table 5.1 Ten largest river basins draining into the Baltic Sea. The runoff values refer to the period 1950-90 (BACC Author Team 2008)

\begin{tabular}{|c|c|c|c|c|c|c|}
\hline River & Country & Area $\left(\mathrm{km}^{2}\right)$ & $\begin{array}{l}\text { Percentage of } \\
\text { Baltic Sea } \\
\text { drainage basin }\end{array}$ & $\begin{array}{l}\text { Mean annual } \\
\text { discharge } \\
\left(\mathrm{m}^{3} \mathrm{~s}^{-1}\right)\end{array}$ & $\begin{array}{l}\text { Percentage of } \\
\text { total river inflow } \\
\text { to the Baltic Sea }\end{array}$ & $\begin{array}{l}\text { Run-off } \\
\left(1 \mathrm{~km}^{-2} \mathrm{~s}^{-1}\right)\end{array}$ \\
\hline Neva & Russia/Finland & 281,000 & 16.1 & 2460 & 17.6 & 8.8 \\
\hline Vistula & Poland/Ukraine/Belarus/Slovakia & 194,400 & 11.2 & 1065 & 7.6 & 5.5 \\
\hline Odra & Poland/Germany/Czech Republic & 118,900 & 6.8 & 573 & 4.1 & 4.8 \\
\hline $\begin{array}{l}\text { Nemunas } \\
\text { (Lithuanian) }\end{array}$ & Belarus/Lithuania/Russia & 98,200 & 5.6 & 632 & 4.5 & 6.4 \\
\hline Daugava & $\begin{array}{l}\text { Belarus/Latvia/Lithuania/Estonia/ } \\
\text { Russia }\end{array}$ & 87,900 & 5.1 & 659 & 4.7 & 7.5 \\
\hline Narva & Estonia/Russia & 56,200 & 3.2 & 403 & 2.9 & 7.2 \\
\hline Kemi & Finland & 51,400 & 3.0 & 562 & 4.0 & 11.0 \\
\hline Göta & Sweden & 50,100 & 2.9 & 574 & 4.1 & 11.5 \\
\hline Torne & Sweden/Finland & 40,100 & 2.3 & 392 & 2.8 & 9.8 \\
\hline Kymi & Finland & 37,200 & 2.1 & 338 & 2.4 & 9.1 \\
\hline Total & & $1,015,400$ & 58 & 7658 & 55 & $8.2^{\mathrm{a}}$ \\
\hline
\end{tabular}

${ }^{a}$ Denotes average value 
understanding of the Baltic Sea catchment hydrology based on publications up to 2006. The BALTEX database of river run-off was utilised for the period 1921-1998. The key findings of the 2008 assessment are summarised in Box 5.1.

\section{Box 5.1 Key findings of the first assessment of climate change in the Baltic Sea basin}

Annual and seasonal variation in total river inflow:

- The average annual inflow to the Baltic Sea for 1921-1998 was $14,119 \mathrm{~m}^{3} \mathrm{~s}^{-1}$ or $445 \mathrm{~km}^{3}$ year $^{-1}$, excluding the Danish belts and sounds.

- The wettest year was 1924 with an inflow of $18,167 \mathrm{~m}^{3} \mathrm{~s}^{-1}$ (+28\% compared to the average annual inflow), and the driest year was 1976 with an inflow of $10,553 \mathrm{~m}^{3} \mathrm{~s}^{-1}(-25 \%)$.

- The wettest decade was the 1990 s with an average annual inflow of $14,582 \mathrm{~m}^{3} \mathrm{~s}^{-1}(+3.3 \%$ compared to the long-term average), and the driest decade was the 1940s with an average annual inflow of $12,735 \mathrm{~m}^{3} \mathrm{~s}^{-1}(-9.8 \%)$.

- No statistically significant linear trend could be found in the time series 1921-1998.

\section{Regional variations and trends in run-off:}

- There were positive trends in run-off for 1920 2002 at several stations in Denmark, southern Sweden and Lapland-although the trends were statistically significant at only two stations. Negative trends were rare and regionally scattered.

- Statistically significant positive trends in run-off were relatively common in winter (DJF) and spring (MAM) in the period 1941-2002 across the northern part of the Baltic Sea drainage basin.

\section{Floods:}

- A widespread pattern of snowmelt floods occurring earlier in the spring was likely to have been the result of higher temperatures.

- A positive phase in the North Atlantic Oscillation (NAO) often indicates high water levels earlier in spring and maximum levels above the long-term average with the opposite tendency in the southern part of the Baltic Sea drainage basin.

Lakes:

- Long-term variations in lake levels in the Baltic Sea basin were not analysed as widely as the variations in river discharge due to the regulation of many lakes: changes in their levels do not correctly reflect variation in climatic or physiographic factors.

Ice regime:

- In the Russian territory of the Baltic Sea basin, the duration of complete ice cover on river decreased during the latter half of the twentieth century: by $25-30$ days on northern rivers and $35-40$ days on southern rivers. The maximum ice-cover thickness decreased $15-20 \%$ on all rivers studied.

- In Finland, in a data series extending to late seventeenth century, the ice break-up on lakes has moved 6-9 days earlier per hundred years. Since late nineteenth century, freezing has delayed by 0 8 days per century.

\subsection{Basin-scale Change in Run-off Patterns}

The Baltic Sea can be considered a large, semi-enclosed brackish water estuary draining into the North Sea via the Danish Straits. The inflow from rivers to the Baltic Sea is an important variable for both the physical and ecological processes of the sea. The form of precipitation falling on its drainage area has a major impact on the annual run-off regime. In winter, much of the precipitation is stored as snow, especially towards the northern part of the basin. Consequently, water levels and discharges in the northern area are at their lowest towards the end of the winter, before snowmelt. The highest water levels and discharges are recorded in spring or early summer owing to snowmelt. Water levels and discharges usually decrease during summer when evaporation/evapotranspiration is greatest and is normally larger than precipitation. Sometimes, if the summer is dry and warm, water levels can even drop below the winter minimum. Climate change is likely to have a clear influence on the seasonal flow regime as a direct response to changes in the form of the precipitation, as well as by altering the temperature-evapotranspiration regime.

Hansson et al. (2011) reported - based on temperature and atmospheric circulation indices from 1500 onwards - that runoff to the Baltic Sea appears strongly linked to temperature, wind and rotational circulation components in the northern region and Gulf of Finland. In contrast, run-off in the southern region is more associated with the strength and torque of the cyclonic or anti-cyclonic pressure systems. Although decadal and regional variability is large, no statistically significant long-term change has been detected in total river run-off to the Baltic Sea over the past 500 years (Fig. 5.3).

Analysis of run-off sensitivity to temperature suggests that the southern regions may become drier with rising air temperatures, whereas in the north and around the Gulf of Finland higher temperatures are associated with greater river run-off. As a whole, over the past 500 years, the total river run-off to the Baltic Sea has decreased slightly in response to the rise in temperature, at a rate of $3 \%$, or $450 \mathrm{~m}^{-3} \mathrm{~s}^{-1}$, per $1{ }^{\circ} \mathrm{C}$ (Fig. 5.4). 


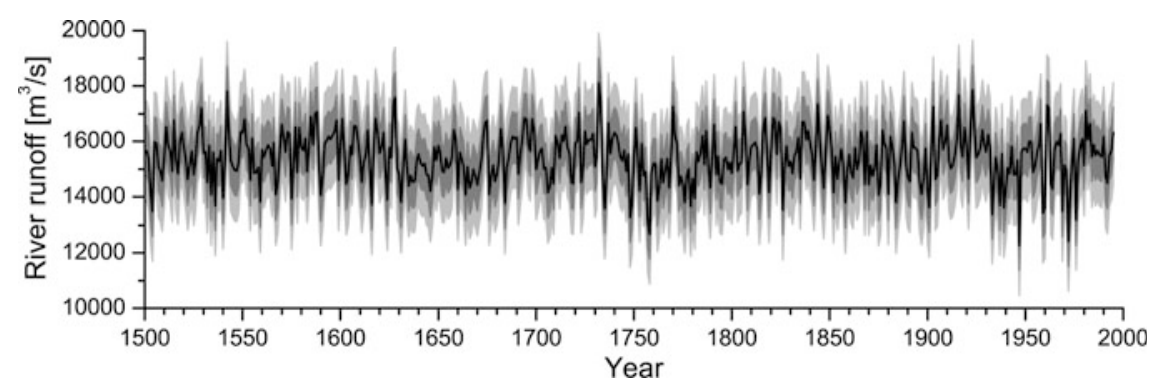

Fig. 5.3 Reconstructed annual river discharge to the Baltic Sea for the past 500 years. The grey shading indicates 1 and 2 standard errors of the reconstructed river discharge (Hansson et al. 2011)

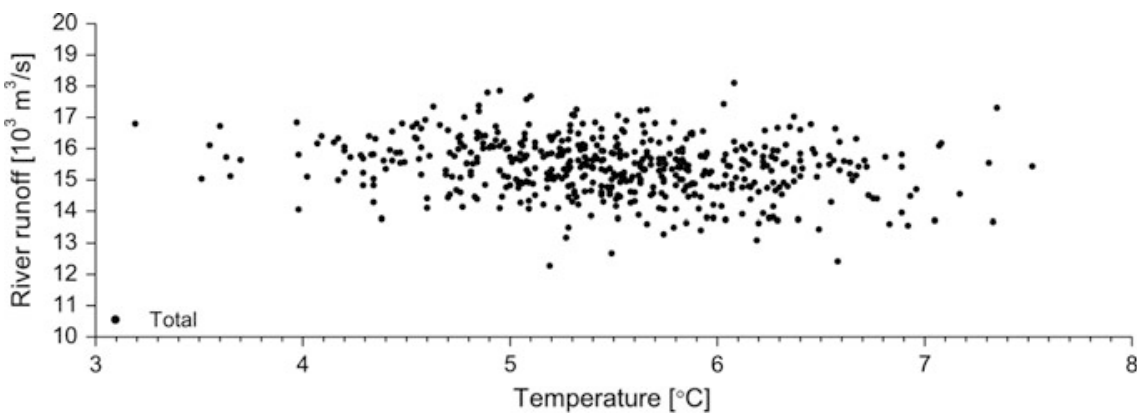

Fig. 5.4 Reconstructed total river run-off as a function of temperature in the Baltic Sea drainage basin for $1500-1995$. A change of $1{ }^{\circ} \mathrm{C}$ results in a decrease in river run-off of $3 \%\left(450 \mathrm{~m}^{-3} \mathrm{~s}^{-1}\right)$ (significant at the $95 \%$ confidence level) (Hansson et al. 2011)

Regarding flow changes on a decadal scale, Hisdal et al. (2010) revised and extended their earlier analysis included in the first Baltic Sea assessment report (Hisdal et al. 2003; BACC Author Team 2008). Currently, the data comprise more than 160 streamflow records from the Nordic countries. The Mann-Kendall trend test was applied to study changes in annual and seasonal streamflow as well as floods and droughts for three periods: 1920-2002, 1941-2002 and 1961-2000.

Regional patterns detected by Hisdal et al. (2010) were influenced by the time period and the selection of stations. However, in general, trends towards increased streamflow dominated annual values (Fig. 5.5) and winter and spring seasons. Trends in summer flow were highly dependent on the period analysed while no trends were found for autumn.
A signal towards earlier snowmelt floods was clear. Comparison of the findings to various streamflow scenarios showed the strongest trends detected to be coherent with changes expected during the scenario period, for example increased winter discharge and earlier snowmelt floods.

Hisdal et al. (2010) concluded by suggesting that the observed temperature increase has clearly affected streamflow in the Nordic countries. These changes correspond well to the projected consequences of a continued rise in global temperature, whereas the impacts of both the observed and projected changes in precipitation on streamflow are unclear.

The analyses by Hisdal et al. (2010) were further refined by Wilson et al. (2010) who considered the effect of spatial and temporal autocorrelation, investigated trend magnitude instead of statistical significance and extended the period
Fig. 5.5 Trends in annual streamflow within the Nordic countries for 1920-2002 (left), 1941-2002 (middle) and 19612000 (right) (Hisdal et al. 2010)

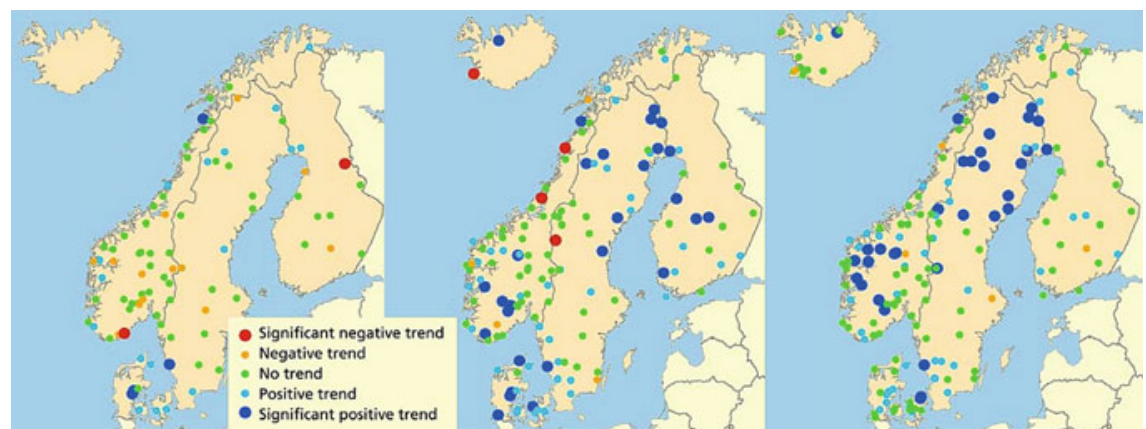


covered to 2005. They also applied the Mann-Kendall trend test to study changes in annual and seasonal streamflow as well as floods and droughts for three periods: 1920-2005 (68 stations), 1941-2005 (111 stations) and 1961-2000 (151 stations). The overall picture was that trends of increased streamflow dominate annual values and the winter and spring seasons. In all three periods, a signal towards earlier snowmelt floods was clear, as was the tendency towards more severe summer droughts in southern and eastern Norway. The trends in streamflow result from changes in both temperature and precipitation, but the temperatureinduced signal is stronger than precipitation influences. This is a consequence of temperature affecting the timing of snowmelt and thus the seasonal distribution of flows rather than annual totals. A change in the timing of the spring flood has also been observed due to changes in the timing of snowmelt.

The tendency for a decrease in annual discharge in the southern catchments recognised by Hansson et al. (2011) was also detected by Gailiušis et al. (2011). They studied the variability of long-term monthly run-off in five rivers draining into the Baltic Sea: the Nemunas, Neva, Odra, Vistula and Luleälven. More than 100 years of data are available for all five rivers, and the data for the Nemunas at Smalininkai starting in 1812 are one of the longest data sets for river run-off in Europe. Variability within the long-term run-off series was analysed by comparing the annual, highest and lowest monthly river discharges against the long-term mean to derive 'anomalies', integrated curves of annual discharges and the results of the Mann-Kendall trend test. A decrease of about $10 \%$ in annual discharge was observed in the rivers on the southern shore of the Baltic Sea (Fig. 5.6). Cyclical variation with an amplitude of 26-27 years in the annual discharge data series is characteristic of the Nemunas, Neva, Vistula and Odra rivers.

Variability in river discharge depends on natural environmental factors, especially on the cyclic variation in precipitation. However, drier and wetter phases in the studied rivers do not occur at the same time. The low phases in the annual discharges of the Nemunas and Neva have a lag of about 12 years compared to those of the Odra and Vistula. Discharge in the Luleälven is affected by high regulation. For a discussion of the impacts of damming and river regulation, see Chap. 17.

\subsection{Regional and Seasonal Variations}

\subsubsection{Sub-basin-scale Changes}

Centennial-scale change in historical sub-basin-scale river discharge has been modelled by Graham et al. (2009). They used the coupled atmosphere-ocean global climate model ECHO-G (Legutke and Voss 1999) downscaled with the Rossby Centre Regional Climate Model RCA3 (Samuelsson et al. 2010) for simulating temperature and precipitation. The results were used in the Hydrologiska Byråns Vattenbalansavdelning (HBV) hydrological model (Bergström 1976, 1992) to simulate river flows to four sub-basins of the Baltic Sea for the periods 1000-1199 and 1551-1929. Observations for the period 1921-2002 were used as reference. The basins studied were the Bothnian Bay, Bothnian Sea, Gulf of Finland and Gulf of Riga. For the southern basin (Gulf of Riga), the earlier periods have had higher river flow, while for the northernmost basin (Bothnian Bay) recent years show a slight increasing trend (Fig. 5.7).

In the Baltic States (Lithuania, Latvia and Estonia) in general, changes in streamflow over the twentieth century show a redistribution of run-off throughout the year: with a significant increase in winter river discharge and a tendency for decreasing spring floods (Reihan et al. 2007). Correlation between streamflow, air temperature and precipitation for the periods 1923-2003, 1941-2003 and 1961-2003 for a total number of 70 stations with a record length of 84 years of daily discharge data shows the strongest relations to occur in winter. Increasing winter discharge seems to be associated
Fig. 5.6 Change in average annual discharge with the cyclicity of about 27 year amplitude for the Nemunas and Odra (Oder) rivers (left axis) and for the Vistula and Neva rivers (right axis) (Gailiušis et al. 2011)

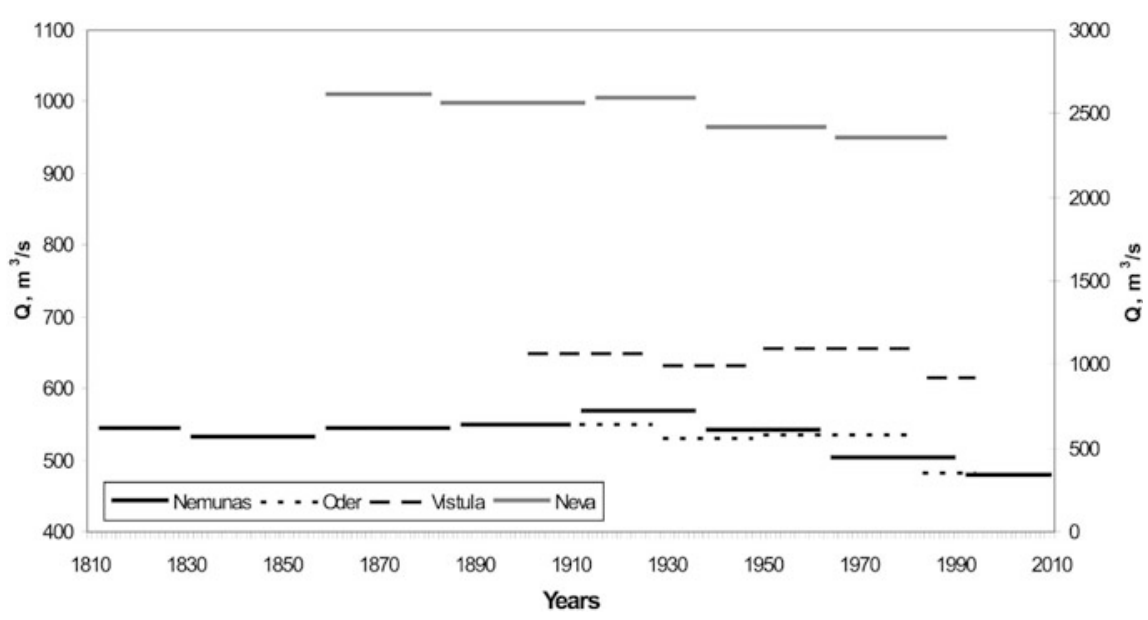


Fig. 5.7 Annual river flow to a Bothnian Bay, b Bothnian Sea, c Gulf of Finland, d Gulf of Riga for the periods AD 1000-1199 and 1551-1929 according to the HBV-Baltic simulation. The observed period 1921-2002 is shown in grey (Graham et al. 2009, modified)
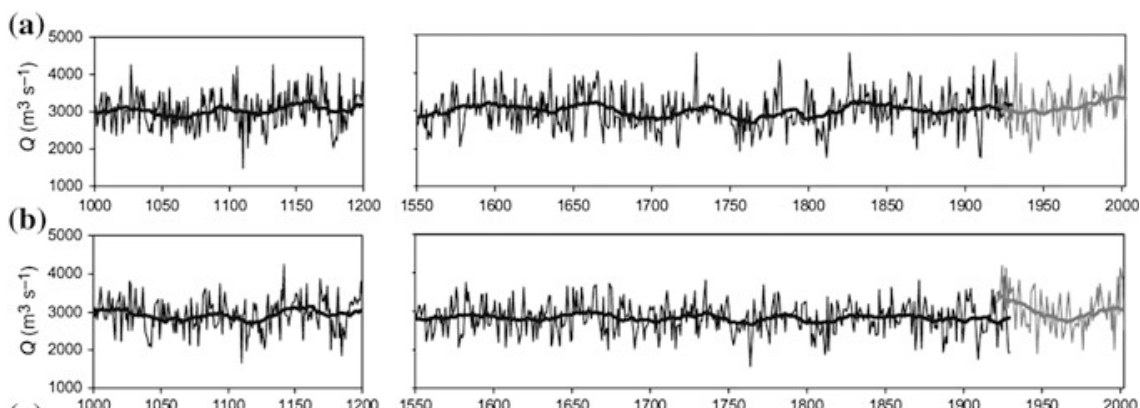

(c)
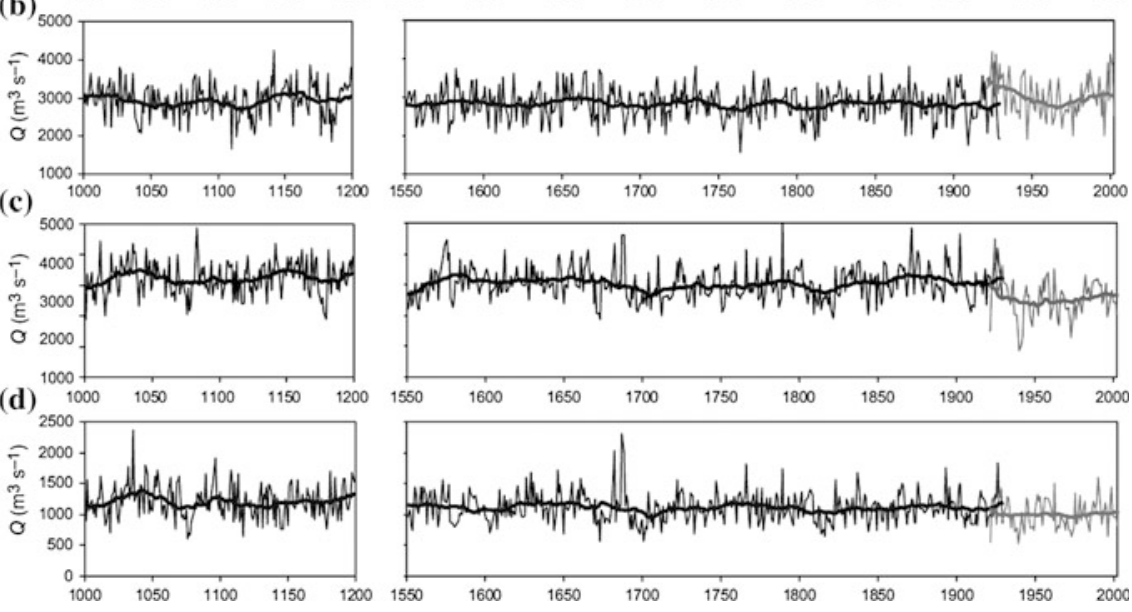

with the significant rise in winter temperature. Average winter temperature in the Baltic States for 1961-2003 rose by $3{ }^{\circ} \mathrm{C}$ and precipitation by $43 \mathrm{~mm}$, while run-off increased by $19 \mathrm{~mm}$. A significant decrease in spring floods was also found.

There was no systematic pattern for the other seasons although differences in streamflow (no change, positive change and negative change) during summer and autumn in most cases reflect tendencies in precipitation and temperature. Although a clear tendency for low summer flow was lacking, a tendency for more years with low-water flow was found. In most cases, changes in river discharge were similar to the Nordic results reported by Hisdal et al. (2010). However, the decrease in spring floods in the Baltic rivers contrasts with the situation in the Nordic countries, where changes in winter snowmelt are not yet apparent in the river run-off data although they are expected in the future
(Veijalainen et al. 2010). In general, the relation between the main meteorological and hydrological parameters and tendencies in river discharge trends is common across all three Baltic States and may reflect the regional impact of global climate change.

Kḷavinš et al. (2007, 2008) and Kḷaviņš and Rodinov (2008) studied river run-off in the Baltic region with an emphasis on Latvia. The variability in long-term run-off for 1881-2006 was investigated in ten Latvian rivers and compared with rivers in neighbouring countries: Neva and Narva (Russia), Nemunas (Lithuania) and Pärnu (Estonia). The observation period of more than 150 years at the Riga University Meteorological Station shows that mean annual temperature has risen about $0.8{ }^{\circ} \mathrm{C}$ over the past century. A good coherence was found between changes in annual precipitation and run-off for the largest rivers in Latvia and other rivers in Baltic region (Fig. 5.8).
Fig. 5.8 Long-term change in precipitation and mean annual discharge for rivers in the Baltic Sea basin: 1 precipitation (Station Rīga University); 2 Nemunas; 3 Daugava; 4 Narva; 5 Pärnu. Curves 1-4: left axis, curve 5: right axis. Data were smoothed using a 6-year moving average

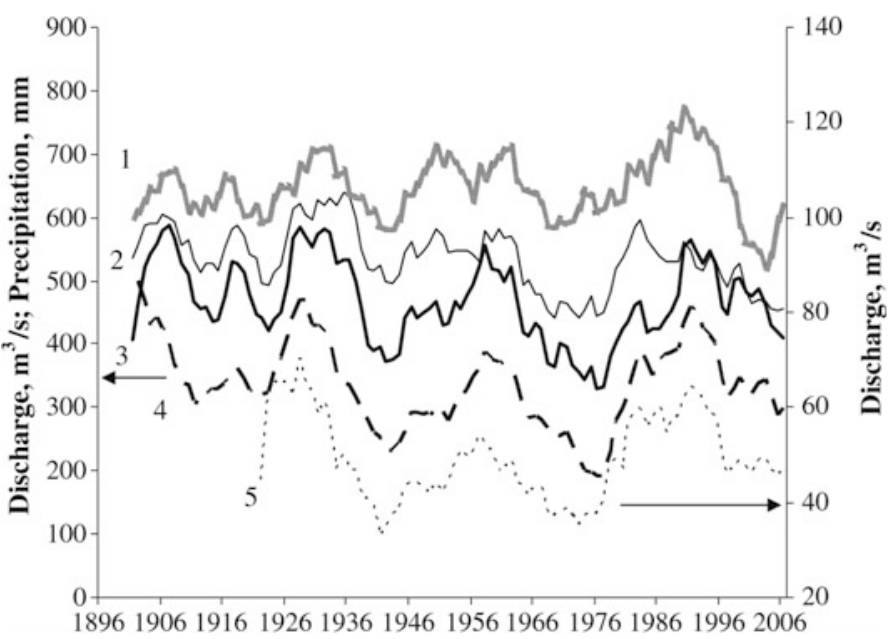


An increasing trend in annual mean discharge for the period 1961-2000 was found in all rivers although the trend was statistically significant in the Daugava, Gauja, Narva, Pärnu, Salaca, Dubna, Irbe and Abava rivers only. For all periods with regular hydrological observations, linear trend analysis showed a statistically significant decrease in discharge for River Nemunas (1896-2006), but for all other rivers the trends were not statistically significant. However, it was evident that discharge showed a stronger increase when the period analysed was reduced to the past 50 years. A particularly marked increase in winter discharge was detected over the past two decades. Discharge, precipitation and temperature trends were more pronounced in catchments further from the coast.

Trend analysis of the annual maximum and minimum discharges for the major rivers Daugava, Lielupe, Venta, Gauja and Salaca indicates a statistically significant decrease in maximum discharge (except for River Salaca) and a statistically significant increase in minimum discharge (except for River Gauja). The greatest number of years (3-6) with extremely high (probability $\leq 10 \%$ ) annual discharge for the major rivers in Latvia occurred during the high-flow periods of 1951-1962 and 1922-1936. Maximum discharge levels have been at their lowest over the past 50 years.

Periodic oscillations in discharge intensity and low- and high-water flow years are common for major rivers in Latvia as well as for those in the Baltic Sea region as a whole. Klaviņš et al. (2008) found good coherence between changes in annual precipitation and river discharge. Spectral analysis revealed the following statistically significant periods of cyclicity in annual river discharge in the Baltic region: 38, $28,14,19,5,4$ and 3 years. For the past 100-125 years in Latvia, low-discharge periods have been longer than highdischarge periods, lasting from 10 years up to a maximum of 21-27 years.

The winter increase and spring decrease in run-off in the Baltic States were also found by Kriaučiūnienè et al. (2012). They analysed the climate change impact on water resources in Estonia, Latvia and Lithuania $\left(175,000 \mathrm{~km}^{2}\right)$ since the 1920s. Long-term temperature (40 stations), precipitation (59 stations) and river discharge (77 stations) data were used to generate ten regional data series for 1923-2007. Changes in the regional series between 1991-2007 and 1931-1960 were analysed against 1961-1990 as a reference period. The impact of changes in temperature and precipitation on river discharge was also assessed.

Anomalies in the regional discharge series depend on the climate type (marine or continental) and the sources feeding the rivers (precipitation, snowmelt, groundwater). Discharge in winter increased everywhere by $20-60 \%$ compared with the reference period. A 10-20\% decrease in spring discharge occurred in the western regions of all Baltic States (marine climate zone), but there were no significant changes in spring discharge in the continental regions (south-eastern Lithuania and Latvia, eastern Estonia) (Fig. 5.9).

\subsubsection{Regional Discharge Patterns by Country}

River catchments are commonly shared by two or more countries, while hydrological offices and authorities operate on a national basis. Therefore, formulating a coherent picture of the hydrology of the Baltic Sea catchment area is complicated. However, international research projects and collaboration between national authorities allow the collection of discharge information by country as well as by catchment. The rest of this section reports the latest information on river flow to the Baltic Sea summarised by country. For Belarus, Denmark and Germany, no new information was available; see also BACC Author Team (2008).

\subsubsection{Estonia}

Reihan et al. (2007) analysed 14 daily streamflow records ranging in length from 45 to 98 years for the period 19032004. The tendency for a decrease in spring floods was notable in all periods for $80 \%$ of stations over the continental regions. No trend was detected in spring, summer and autumn run-off, nor in summer droughts.

Long-term discharge trends were analysed by the Estonian Meteorological and Hydrological Institute (EMHI 2011) for the period 1957-2006 for 23 Estonian gauges. Trends were investigated by applying the Mann-Kendall test with a $5 \%$ significance level. Annual mean run-off shows a significant positive trend over all Estonia except for the Narva river. The changes in annual run-off follow the changes in precipitation. Spring flood maximum discharge shows a significant negative trend over Estonia, while winter flood maximum discharge shows a significant positive trend over the country. Summer flood maximum discharge has increased in eastern Estonia, while a decrease has occurred in central and western parts of the country.

\subsubsection{Finland}

The published data on water level and flow regimes in the rivers of Finland extend until 2004 (Korhonen 2007; Korhonen and Kuusisto 2010). The monthly and annual mean outflow from the whole territory has been determined for the period 1912-2004, complemented by 25 discharge time series and 13 water level time series. Both unregulated and regulated rivers were examined. While most of the observation series examined started from the $1910 \mathrm{~s}$ to $1930 \mathrm{~s}$, the longest continuous records date back to the mid-1800s.

The mean outflow from Finland in 1912-2004 was about $3300 \mathrm{~m}^{-3} \mathrm{~s}^{-1}$ (Fig. 5.10). The variation in annual mean discharge was $18 \%$. The lowest annual outflow from 
Fig. 5.9 Seasonal and regional anomalies in river discharge in the Baltic States in 1991-2007 relative to the reference period 1961-1990. WIN winter, SPR spring, SUM summer, AUT autumn (Kriaučiūnienė et al. 2012)

Fig. 5.10 Time series and trends in mean annual (MQ), winter (DJF), spring (MAM) and summer (JJA) outflow from Finland in 1912-2004. Only statistically significant trends are shown (Korhonen and Kuusisto 2010)
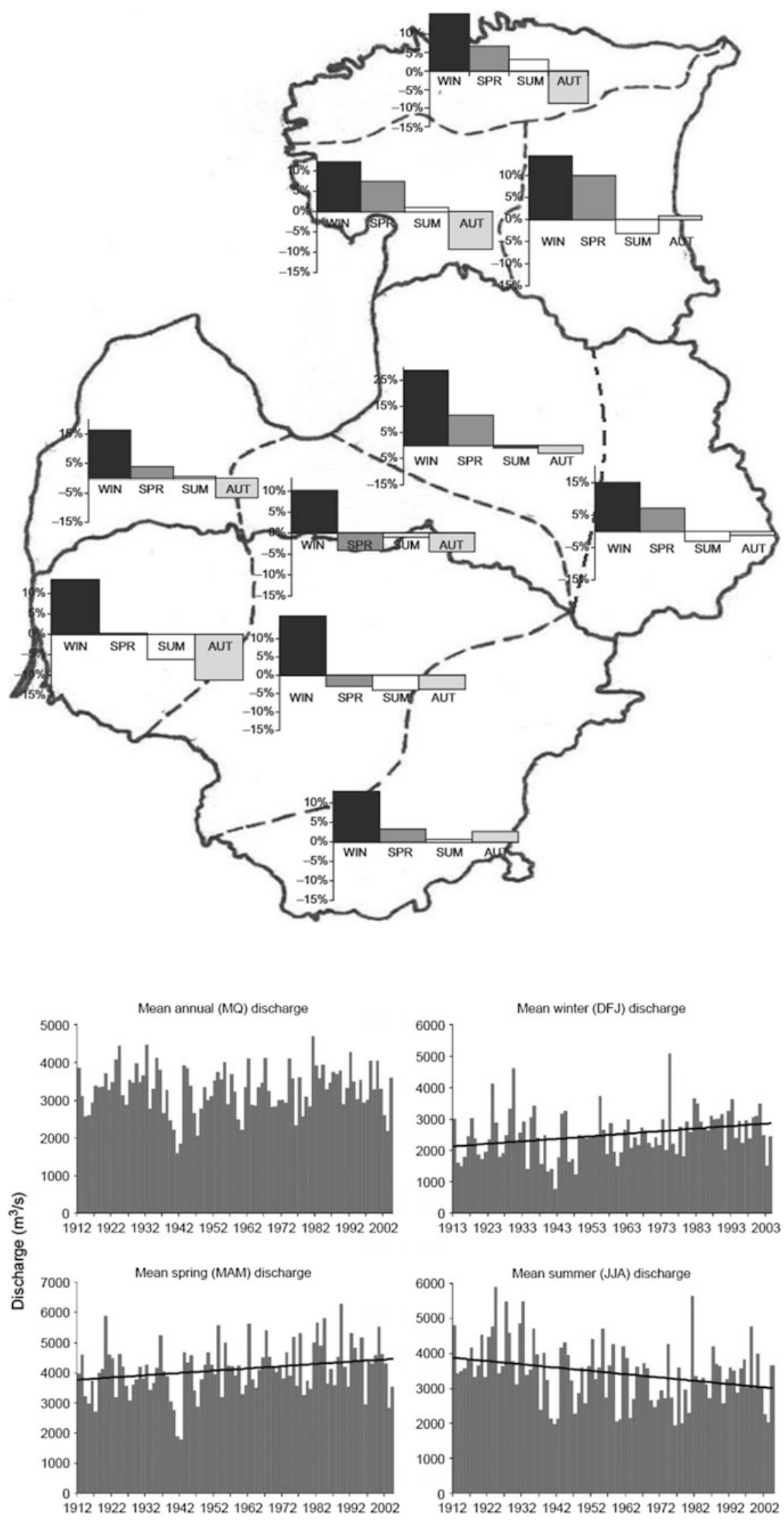
Finland was about $1600 \mathrm{~m}^{-3} \mathrm{~s}^{-1}$ in 1941 and the highest about $4700 \mathrm{~m}^{-3} \mathrm{~s}^{-1}$ in 1981, giving a ratio of about $3: 1$ between the highest and lowest annual outflow. The highest monthly outflows have normally been recorded in May during snowmelt floods, with a record value of about $10,350 \mathrm{~m}^{-3} \mathrm{~s}^{-1}$ in May 1920. The lowest monthly mean outflow was $640 \mathrm{~m}^{-3} \mathrm{~s}^{-1}$ in March 1942 giving a ratio of about 16:1 between the highest and lowest monthly outflow. Normally, outflow is lowest in winter and peaks in spring or early summer. The relative variation in monthly mean outflow was lowest in May (22\%) and highest in September (35\%).

The discharge regime has changed over the decades in response to both climatic fluctuations and human impacts, predominantly water regulation. Although there is no statistically significant change in the annual mean outflow from Finland for 1912-2004, climate change has affected the annual cycle of flow, particularly the seasonal distribution of flow. The most significant change has occurred in the hydrological regimes of winter and spring. Both seasons have become milder during the twentieth century (see also Chap. 4, Sect. 4.4), and consequently, late-winter and earlyspring mean discharges have increased. However, the magnitudes of spring peak flow have not changed. Regulation has increased the winter and spring mean discharge in some places, while the summer flow has decreased. Winter and spring monthly mean discharges from Finland increased by 100-150 $\mathrm{m}^{-3} \mathrm{~s}^{-1}$ per decade during 1912-2004. June and July monthly mean discharges from Finland decreased by 85-195 $\mathrm{m}^{-3} \mathrm{~s}^{-1}$ per decade. Changes in seasonal discharge were different in different regions. Most drainage basins in Finland are affected by regulation, but especially in northern Finland and in Ostrobothnia. Winter and spring discharge increased mostly in the north, whereas summer discharge decreased specifically in southern Finland.

Long-term changes in the individual discharge time series were similar to the changes in the outflow from Finland. At most sites, the winter and spring mean discharges increased at both unregulated and regulated sites. However, in northern Lapland, it seems more likely that winter discharge decreased. The increase in winter discharge focused on late winter and the increase in spring discharge on early spring. The rise in winter and spring discharge can almost certainly be attributed to warming in winter and spring and earlier snowmelt. At some regulated sites, the release of water has been increased in winter and early spring in order to increase the storage capacity for snowmelt water. This explains the stronger winter and spring discharge trends at some regulated sites. Spring high flow occurred earlier within the year at about a third of the observation sites. In most cases, this shift in timing was 1-8 days per decade. There is no overall change in the magnitude of spring high flow. At a third of the unregulated sites, summer discharge has increased, whereas there has been a decrease in some monthly discharges at slightly less than half of the regulated sites. The decrease in summer discharge at regulated sites can be at least partly explained by higher water release in winter and spring. At about half of the unregulated observation sites, low flows have increased, at about half of the regulated observation sites they have decreased. Increase in low flow at unregulated sites can be explained by increased discharge in low-flow periods (winter and summer). Decrease in low flow at regulated sites is explained by zero flow when water gates are shut, but a similar situation is usually not possible in unregulated streams. Annual mean flow and annual high flow did not show statistically significant trends in general, apart from at a couple of sites. Changes in mean monthly or seasonal discharge were typically a small percentage of the period mean flow per decade, in most cases not higher than $10 \%$. Trends at regulated sites were stronger than trends at unregulated sites.

\subsubsection{Latvia}

Recent studies of run-off in Latvia include those by Apsīte et al. (2009, 2013). The authors studied a 1951-2009 data series of twenty-five river hydrological stations. The first $37-$ year period (1951-1987) showed 'no substantial' climate change impacts on river run-off, whereas the subsequent 22year period (1988-2009) had a 'substantial' climate change signal in river run-off. In the period 1951-1987, a major part of the total annual river run-off (37-52\%) was generated during spring with a peak discharge of up to $30 \%$ in April, followed by winter (17-30\%), autumn (17-25\%) and summer (9-14\%), with the lowest discharge (2-4\%) in July and August. In comparison with the study period of 19511987, the past two decades (1988-2009) showed a statistically significant mean increase of $11 \%$ in river run-off during winter. In contrast, a statistically insignificant decrease took place in spring (8\%) and autumn (3\%). Summer showed little change.

Although run-off has increased significantly in January and February and decreased significantly in April and May over the past two decades, a major proportion of the total annual river run-off is still generated in spring (39\% on average) and discharge still peaks in April (17\% on average) (Fig. 5.11). Changes in seasonal and monthly river discharges were identified in all four hydrological districts studied (western, central, northern and eastern Latvia), but the greatest change occurred in the central district.

Trend analyses for both periods (1951-2009 and 18812009) suggested a statistically significant increasing trend for winter low flow (the 30-day minimum discharge) and significant decreasing trends for both the high discharge (the maximum discharge of the year) and the coefficient of uneven run-off distribution. Hence, the difference between the low-flow and high-flow discharges in spring has 
Fig. 5.11 Change in river hydrographs between two study periods in hydrological districts of Latvia and in Latvia as a whole. The grey area shows the $95 \%$ confidence interval for the mean discharge values for 19511987. The black triangles represent statistically significant change in monthly mean discharge value for 1988-2009 (Apsīte et al. 2013)
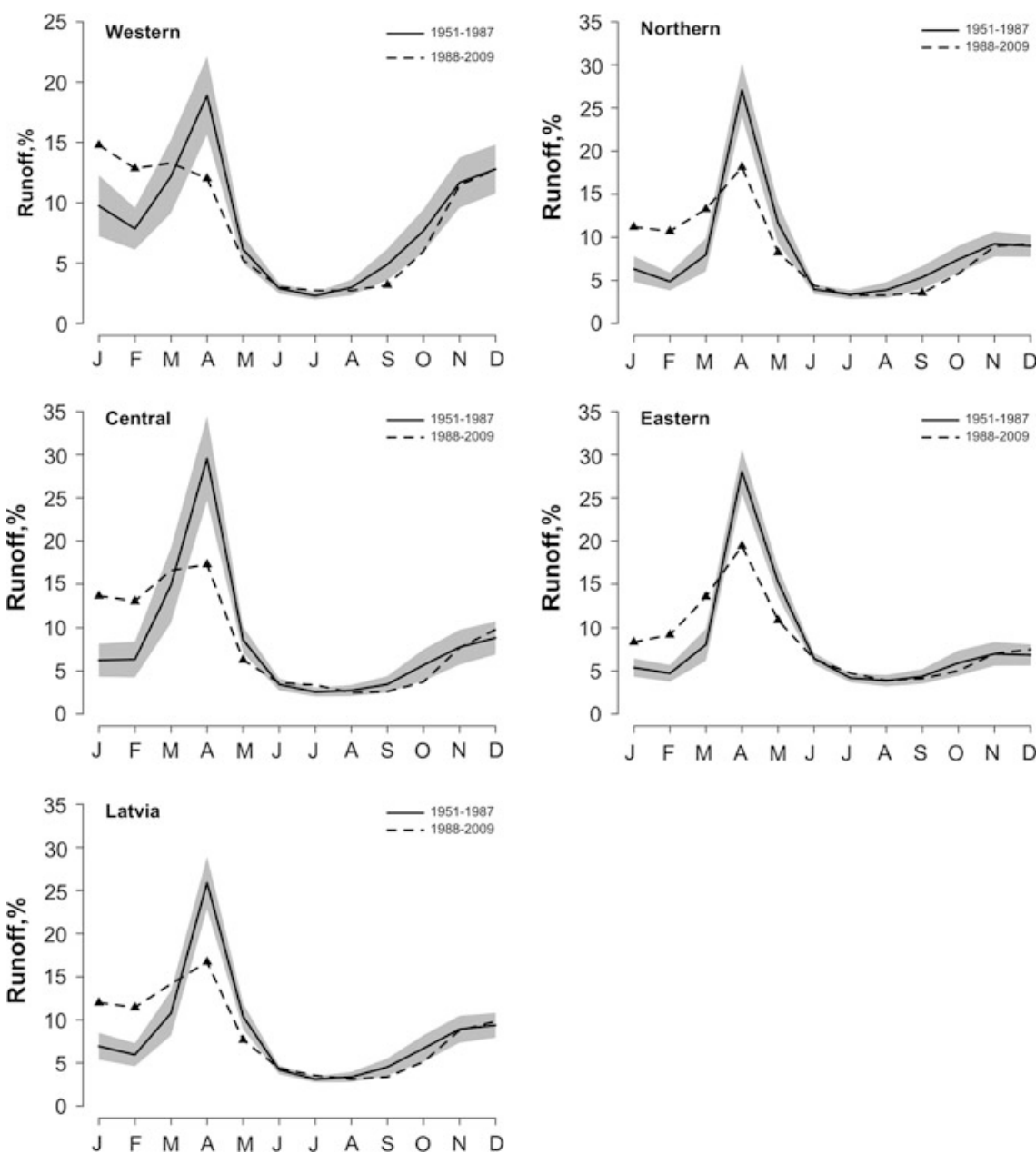

decreased over recent decades, and the annual distribution of run-off has become more uniform. An example of long-term trends in the river Daugava annual discharge at the Daugavpils site is presented in Fig. 5.12, representing one of the longest observed data series in the Baltic countries.

\subsubsection{Lithuania}

The natural climate fluctuation in the Baltic Sea region, including Lithuania, depends partially on the processes of atmospheric circulation (see Chap. 4). Since the 1940s, deep cyclones have been more frequent across Lithuania during
Fig. 5.12 Trends in the 30-day minimum discharge in low flow of cold $\left(Q_{30 \text { cold }}\right)$ and warm $\left(Q_{30}\right.$ warm) periods, annual mean discharge $\left(Q_{\text {mean }}\right)$ and maximum of the year discharge $\left(Q_{\max }\right)$ at the hydrological station DaugavaDaugavpils for the period 18812009. Discharge curves are smoothed with a 5-year moving average (Apsīte et al. 2013)

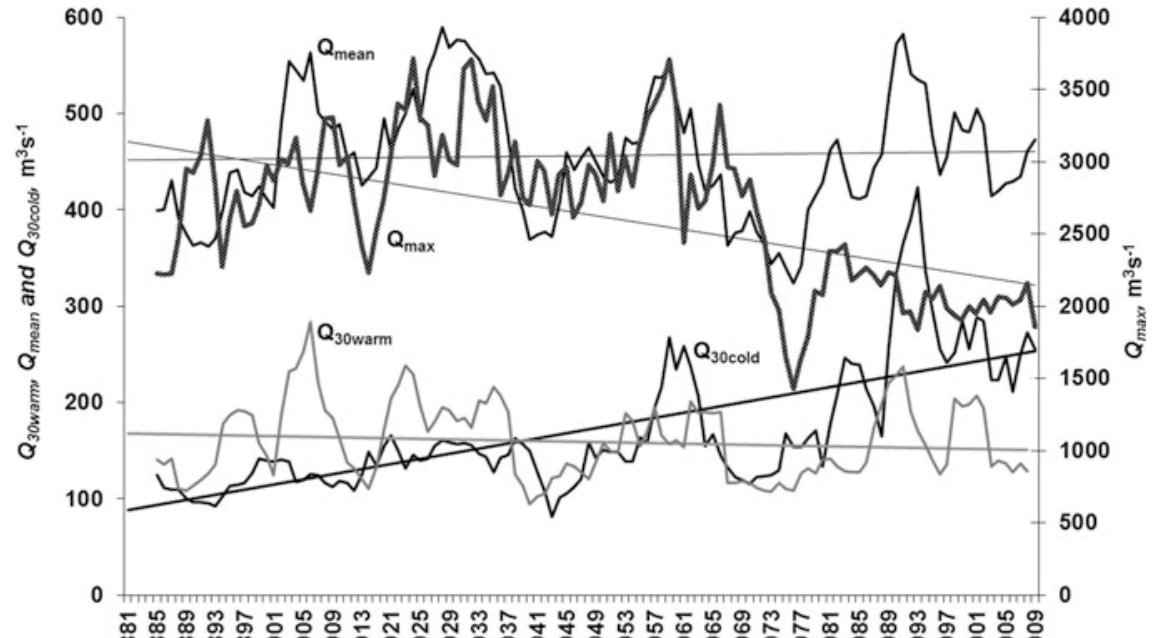

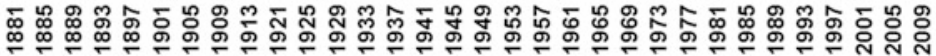


winter (Bukantis et al. 2001). Consequently, winters have become warmer, long-lasting seasonal frost has decreased, and the contrast between seasons has diminished. Unusually, warm periods and the amount of winter precipitation increased in the final decades of the twentieth century in Lithuania.

Meilutytė-Barauskienė et al. (2010) studied Lithuanian rivers with a catchment area larger than $500 \mathrm{~km}^{2}$ using data from 17 meteorological and 32 hydrological stations. Changes in air temperature from 1961-1990 to 1991-2007 in Lithuania can be summarised as follows (Meilutytė-Barauskienė et al. 2010): average annual temperature increased by $1.1{ }^{\circ} \mathrm{C}$, average winter and spring temperatures increased by 0.57 and $0.7{ }^{\circ} \mathrm{C}$, respectively, and the temperature contrast between seasons decreased. Annual and winter precipitation increased by 3 and $17 \%$, respectively. Spring, summer and autumn precipitation showed little change.

Winter run-off increased and spring run-off decreased during the final decades of the twentieth century with only small changes during summer and autumn. Meilutytè-Barauskienè et al. (2010) analysed the run-off time series for annual, seasonal and extreme events using the Mann-Kendall trend test. A summary of significant positive and negative trends is illustrated in Fig. 5.13. A significant negative trend was found in annual and spring, summer and autumn run-off over the period 1922-2003. The same tendency is characteristic for 1941-2003, while winter run-off increased in $54 \%$ of stations. In the period 1961-2003, winter run-off again increased, whereas spring run-off and maximum discharge decreased in $85 \%$ of stations. The smallest changes were found for autumn and summer, especially the driest month, July.

Findings by Kriaučiūnienè et al. $(2008,2012)$ demonstrated an uneven temporal and spatial run-off distribution in
Lithuania. Annual river run-off varies from 4.2 to $14.0 \mathrm{l} \mathrm{s}^{-1} \mathrm{~km}^{-2}$. Lithuania has been divided into three hydrological regions (western, central and south-eastern) according to different types of river feeding (precipitation, snowmelt, groundwater) and hydrological regime. Longterm regional series of temperature, precipitation and run-off compiled for these hydrological regions were analysed against the reference period 1961-1990. Annual temperature for the period 1991-2006 was about $15 \%$ higher than during the reference period, whereas precipitation varied regionally from $-3 \%$ (western region) and $-6 \%$ (central region) to $+4 \%$ (south-eastern region). There was no significant change in run-off in 1991-2006 relative to the reference period. Climate change (increasing air temperature and decreasing summer precipitation) has had an impact on drought characteristics of river run-off (frequency, duration and discharge) in Lithuania. Change in low-flow conditions in Lithuanian rivers was analysed by Kriaučiūnienè et al. (2007). The drought data series were defined as a series of 30-day minimum discharge for the summer low-flow period. Representative historical daily data series from 30 hydrological stations were used to calculate trends. Three time periods (1922-2003, 1941-2003 and 1961-2003) were selected for analysis by the Mann-Kendall trend test. The cyclic variations in the time series of 30-day minimum discharge were typical for all Lithuanian rivers. The average periodicity of the cycles was found to be 27 years, including an average 'wet period' of 13 years and 'dry period' of 14 years. This is in line with the findings of Kriaučiūniene et al. (2012) who found long-term variations in the regional time series of precipitation and discharge in all ten regions studied in Lithuania. The average periodicity of the wet and dry phases was 27-30 years, including an average wet period of 15 years and an average dry period of 14 years
Fig. 5.13 Significant trends in annual, seasonal and extreme runoff from rivers in Lithuania for three periods over the past century. The vertical axis shows the percentage of stations encountering a positive (red) or negative (blue) significant trend (Meilutytè-Barauskienė et al. 2010)

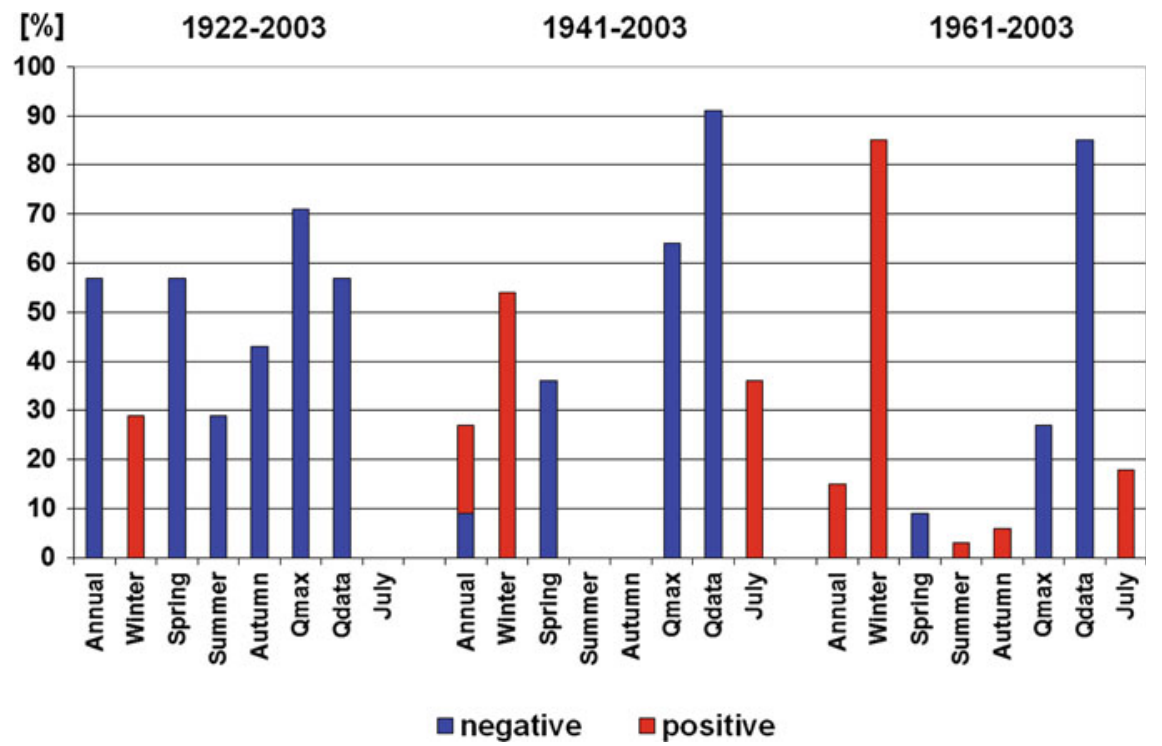


Fig. 5.14 Periodicity in annual $(Q)$ and 30-day minimum discharge $(Q 30 ; 5$-year moving average) in Nemunas, Lithuania (Kriaučiūnienè et al. 2007)

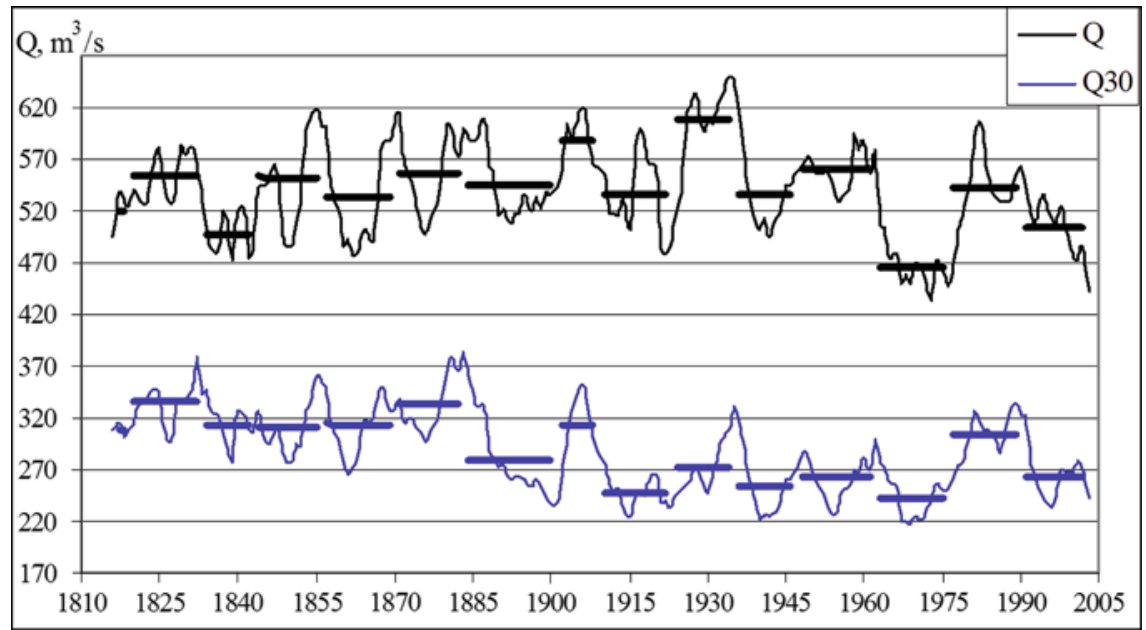

(see also Chap. 4, Sect. 4.5). The final period (1996-2007) of long-term variation in river discharge was considered 'dry', although was only $3 \%$ lower than the multi-year average discharge. This small decrease in discharge is believed to stem from higher temperature despite a small ( $2 \%$ ) increase in precipitation in 1996-2007. The periodicity of variations in annual discharge and 30-day minimum discharge is similar (Fig. 5.14).

The analysis of minimum run-off using the Mann-Kendall trend test revealed no trends in annual variation in 30day minimum discharge for the periods 1922-2003 and 1941-2003. Only a few rivers in western Lithuania had positive trends in the period 1961-2003. In Lithuanian rivers, droughts (30-day minimum discharges) occur in the period June to August. Since 1961, droughts have been observed less frequently in June and more frequently in August.

\subsubsection{Poland}

About $99.7 \%\left(312,683 \mathrm{~km}^{2}\right)$ of Poland lies within the catchment of the Baltic Sea. Analysis of the total run-off from Poland during the period 1951-2010 shows a slight increasing tendency (Fig. 5.15).
Vistula (Wisla) is the longest river flowing into the Baltic Sea and has the second highest run-off after Neva river. The Vistula river catchment covers about $54 \%$ of Poland. Analyses of Vistula discharge during 1921-2006 do not show any increasing tendency, but a periodicity of 1318 years. Run-off is stable over the long term, ranging from a minimum of $18.76 \mathrm{~km}^{3}$ in 1943 to a maximum of $51.09 \mathrm{~km}^{3}$ in 1975. However, the past 20 years show an increasing tendency with the long-term maximum for 1921-2006 $\left(51.09 \mathrm{~km}^{3}\right)$ exceeded in $2010\left(54.58 \mathrm{~km}^{3}\right)$.

The Odra is the second longest river in Poland. Discharge at the Godzdovice gauging station has shown a slight increase over the past couple of decades although there is no trend over the full data series (1921-2006) (Institute of Meteorology and Water Management of Poland).

\subsubsection{Russia}

The Neva is the largest of the rivers flowing into the Baltic Sea, accounting for about $18 \%$ of total run-off (Table 5.1). Figure 5.16 presents monthly and annual run-off for the Neva and Volkhov rivers and shows considerable interannual variability (Filatov et al. 2012). During the final decade, the annual means vary widely from a maximum of $2861 \mathrm{~m}^{3} \mathrm{~s}^{-1}$ in
Fig. 5.15 Annual run-off from Poland in the period 1951-2010 (Institute of Meteorology and Water Management of Poland)

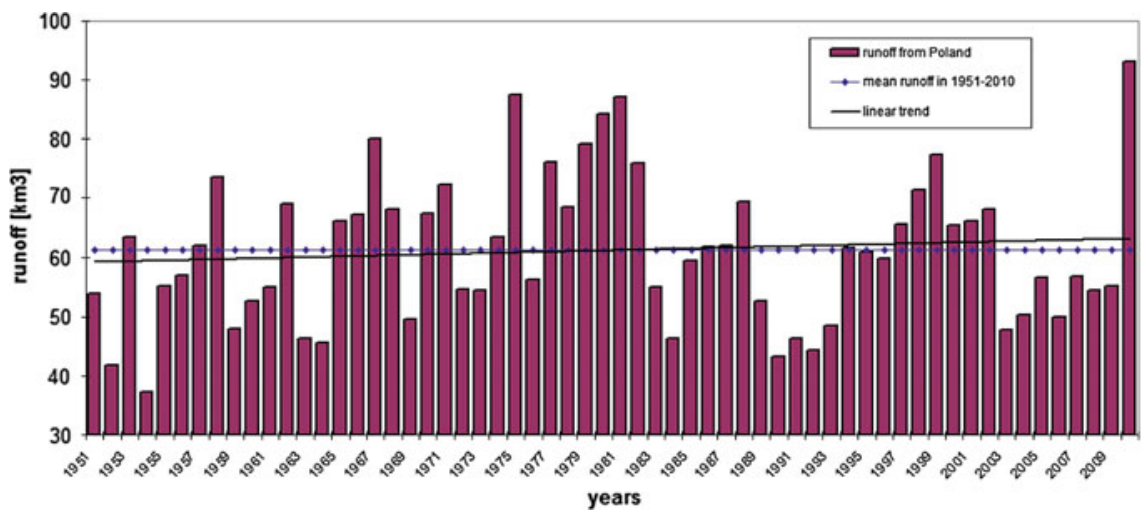


Fig. 5.16 Annual discharge for the Neva (a, left axis) and Volkhov (b, right axis) between 1950 and 2010 (Filatov et al. 2012) for the Shuja (a), Suna (b) and Vodla (c) between 1950 and 2006 (Filatov et al. 2012)
Fig. 5.17 Annual river run-off
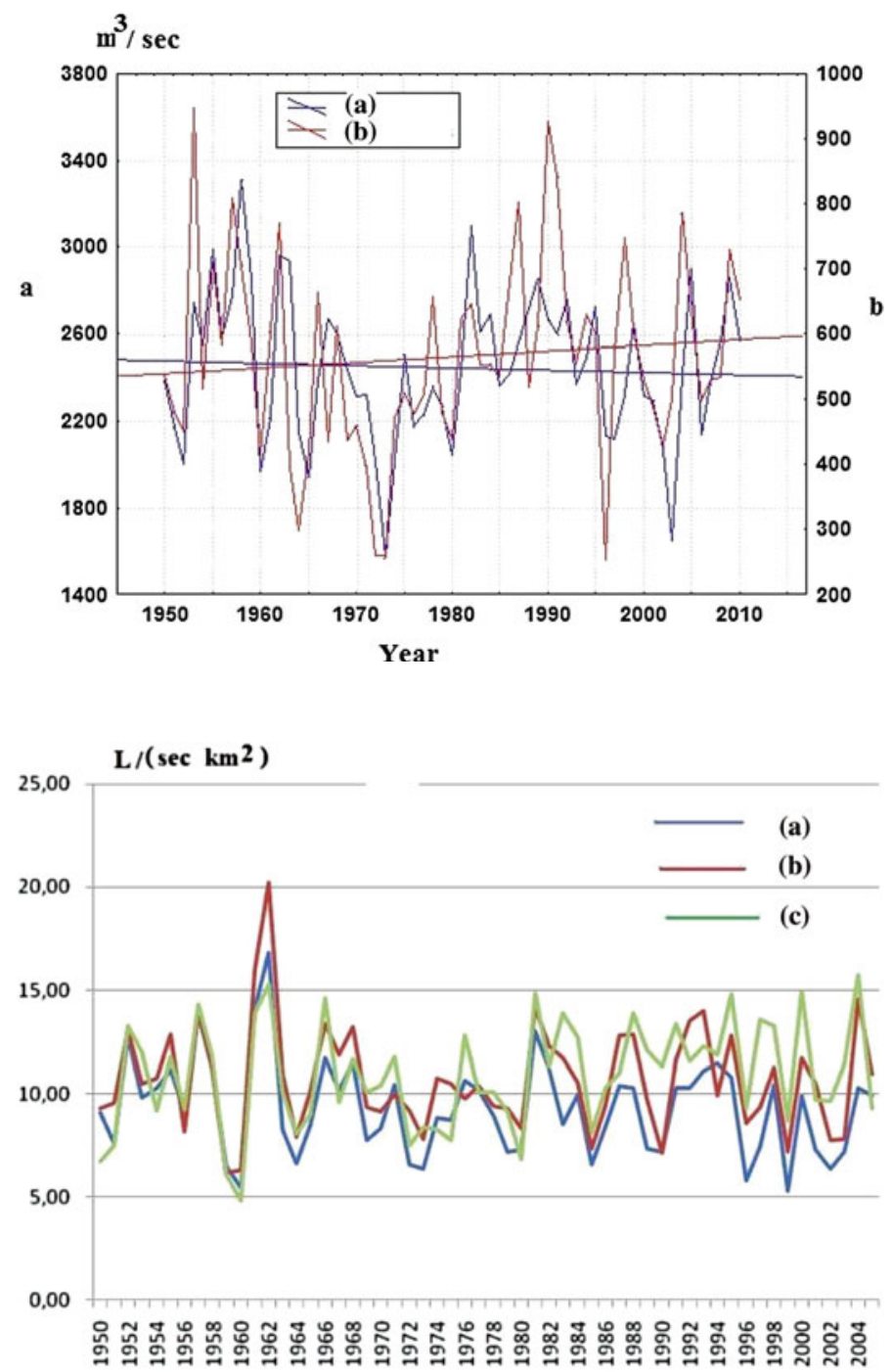

2000 to a minimum $1649 \mathrm{~m}^{3} \mathrm{~s}^{-1}$ in 2003. No statistically significant trends were found in the run-off data, for the Neva or Volkhov rivers, or for the Shuja, Suna or Vodla rivers (Fig. 5.17). Recent decades have been characterised by a combination of high temperature and high run-off.

The Neva river is heavily regulated using the lakes of the catchment, and the share of winter low water accounts for about $25 \%$ of annual run-off (Gronskaja 2008). The river run-off ratio between wet and dry years is roughly $2: 1$. The seasonal river run-off distribution has not changed but spring (AM) run-off has increased by 6-13\% while winter (DJF) run-off has decreased by 4-10\% (Shiklomanov 2008).

\subsubsection{Sweden}

Average long-term series of temperature and precipitation for Sweden were constructed by Alexandersson (2002). These data series were extended and supplemented by hydrological data by Lindström and Alexandersson (2004), Hellström and Lindström (2008) and Lindström (2011), for example. Figure 5.18 shows annual anomalies and long-term variations in precipitation, temperature, water resources and flood magnitude in Sweden for the period 1901-2010. The period 1961-1990. Temperature has been unusually high in recent years, with a temperature anomaly of about $1{ }^{\circ} \mathrm{C}$ for Sweden as a whole. From 1988 onwards, all years except two have been warmer than the average for the reference period. Precipitation has increased much more than run-off. Hellström and Lindström (2008) were not able to establish the reason for this discrepancy, but suggested that the single most likely factor was a change in the precipitation measurement technique. Run-off was fairly stable over the study period. The 1970s was the driest decade (with a deficit of about $10 \%$ compared to the reference mean), while the 1920s, 1980s and 1990s were the wettest (about $+10 \%$ ). 2000 was the wettest year, with a precipitation anomaly of almost $40 \%$. The magnitude of the annual maximum floods in unregulated rivers was relatively stable over the study anomalies are relative to mean values for the reference 
Fig. 5.18 Annual anomalies (relative to 1961-1990) and longterm variability in precipitation, temperature, runoff and flood magnitude in Sweden for 1901-2010. For flood magnitude, the years before 1911 were omitted due to data scarcity (Hellström and Lindström 2008)
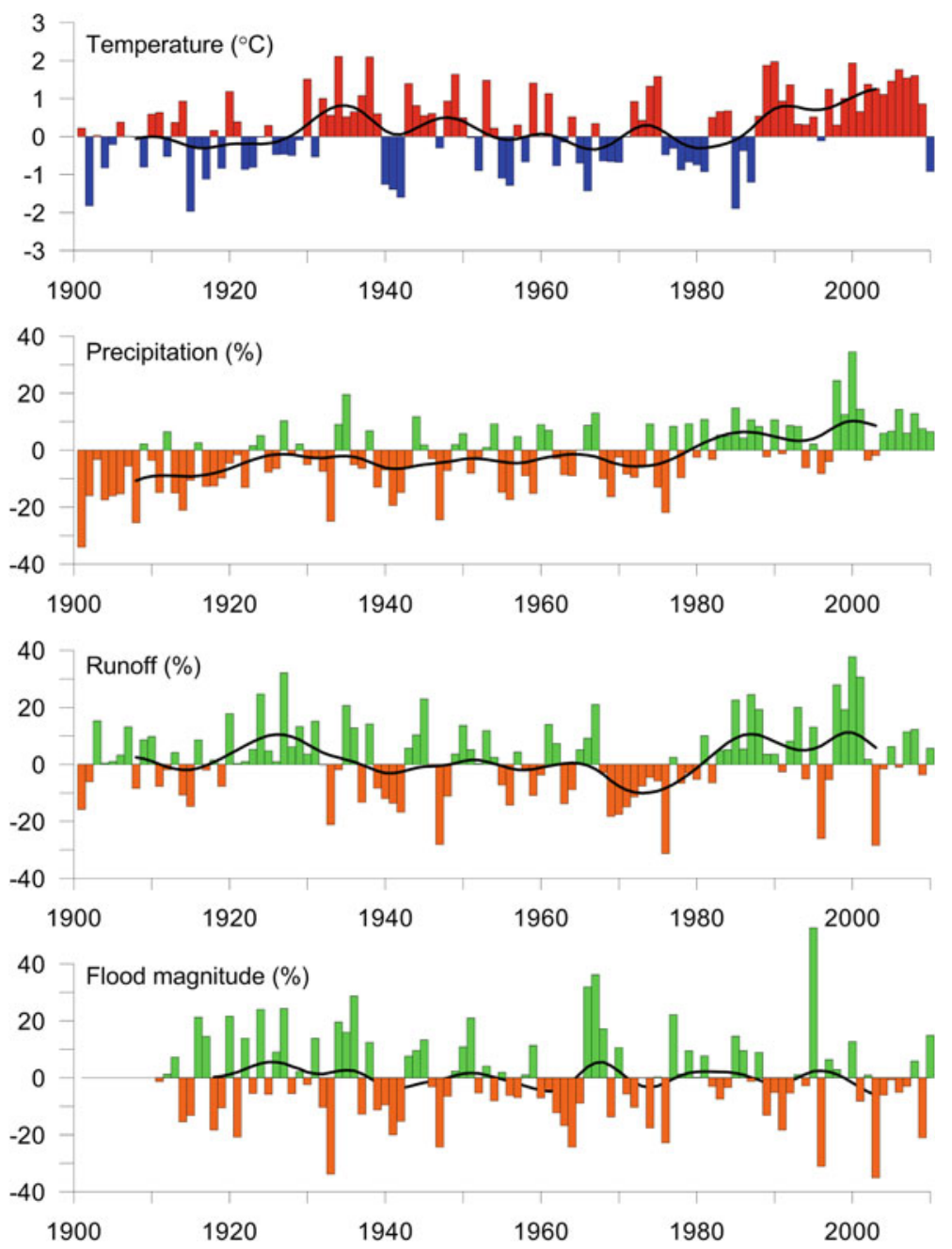

period. 1995 was the year with highest floods on average, and 2003 was the year with lowest flood peaks.

\subsection{River Ice Regime}

The river ice regime is considered a sensitive indicator of climate change. Kļaviņš et al. (2007, 2009) studied longterm changes in ice break-up date and duration of ice cover for 17 river stations in the Baltic countries and Belarus. River Daugava has the longest data series in Europe starting in 1530. A pronounced decreasing trend is apparent for the past 150 years and is even more clearly evident over the past 30 years (Fig. 5.19). No decreasing trend was detected for the initial period (starting 1530), which includes the Little Ice Age. The records of historical observations show recurring episodes of mild and severe winters (see Chap. 4 for the past 200 years and Chap. 3 for the past 1000 years, including the Little Ice Age).
A decreasing linear trend indicates a reduction in icecover duration and earlier ice break-up. The ice-cover duration has declined by 2.8-6.3 days per decade during the past 30 years. In general, the shift in river ice break-up

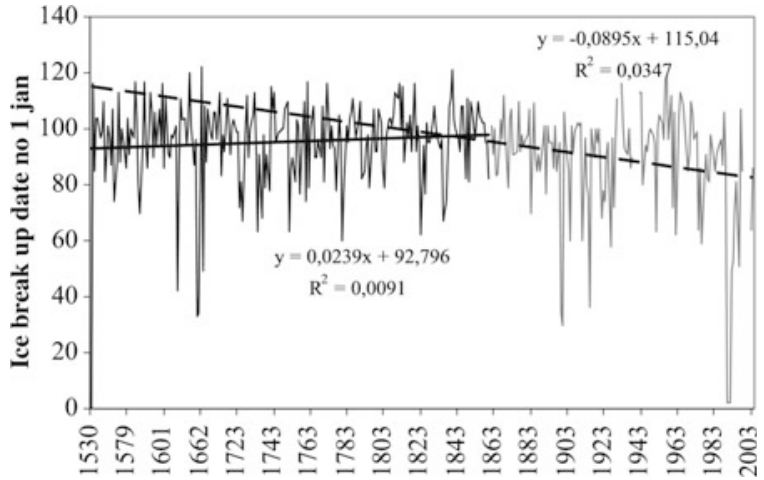

Fig. 5.19 Time series of ice break-up dates on River Daugava (dashed line shows trend from 1860 to 2003 and continuous line from 1530 to 1859) (Kḷaviņš et al. 2009) 
towards earlier dates, indicating an earlier start in river flooding, is in agreement with the increase in winter run-off for rivers in the Baltic Sea basin. The time of ice break-up depends not only on meteorological conditions in a given year and distance from the Baltic Sea, but also on global climate, making it a good integrating indicator of global climate change.

Both the ice regime and the seasonal river discharge are strongly influenced by large-scale atmospheric circulation processes over the North Atlantic, and this is manifested through a close correlation with the NAO (see Chap. 4). A strong negative correlation between the NAO index, Winter Baltic Climate Index (WIBIX, Hagen and Feistel 2005) and ice break-up events suggests that atmospheric processes over the North Atlantic were the main factor driving the river ice regime in the Baltic region for the period 1921-2000 (Kļaviņš et al. 2009). In winter, intense westerly circulation moves fronts and air masses through the mid-latitudes and across the Baltic Sea region, but during the warmer parts of the year it weakens considerably and precipitation events are largely due to different processes.

Stonevicius et al. (2008) reported a decrease in ice-cover duration in the lower reaches of the Nemunas River, Lithuania, over the past 150 years. They argued that variation in the river freeze-up and break-up dates is related to variation in climatic variables. The negative break-up trend exceeds that of the positive freeze-up trend. Low-frequency, large-scale atmospheric circulation patterns such as the NAO and the Arctic Oscillation (AO) (see Chap. 4) appear to have more influence on the break-up date than on the freeze-up date.

Šarauskienè and Jurgelènaitė (2008) studied ice-cover data for 13 water measurement stations on eight rivers also in Lithuania. Variation in ice-cover data was investigated for three periods: 1931-1960, 1961-1990 and 1991-2005. The study suggests that warmer winters cause later freeze-up dates and shorter ice-cover duration on the rivers. Long-term observations of the Nemunas (1812-2006) at the Smalininkai station indicate that in the nineteenth century, ice cover formed on average 13 days earlier and remained unbroken on average for 30 days longer than in the twentieth century. Applying the Mann-Kendall trend test to the data showed very significant trends in the Nemunas ice data series of the last century: a negative trend in ice duration data and a positive trend in freeze-up date data. According to the icecover data, the Kaunas Hydro Power Plant has the largest anthropogenic impact on the Nemunas ice processes. After the dam was constructed in 1959, ice duration at Kaunas and Lampédžiai WMS decreased on average by 15 and 5 days, respectively, compared to the period 1931-1960. Observational data from 1991 to 2005 indicate a strong decrease in ice duration compared to earlier periods. In urban areas, human activities cause rivers to freeze-up later and the period of ice cover to be shorter.

In Russia, the analysis of the interannual variation in ice phenomena dates and the duration of coverage for Lake Ladoga show very small but significant trends (1-6 days per 100 years). The trend is most marked for freeze-up dates (14 days per 100 years) but the coefficient of determination is no more than $3 \%$ (Karetnikov and Naumenko 2008). Change in the thermal regime of the near surface water layer is revealed by the increase in duration of the ice-free period on Lake Onego (Onega) (Salo and Nazarova 2011). By the end of the twentieth century, the number of ice-free days had increased from 217 to 225 days on average (Fig. 5.20). The authors argued that the dates of ice-cover formation and decay on Lake Onego are determined not only by autumn and spring temperatures but also by large-scale processes characterised, for example, by the NAO index. Figure 5.21 illustrates the
Fig. 5.20 Dates of a break-up (red) and freezing (blue), and b duration of ice-free period on Lake Onego (redrawn from Salo and Nazarova 2011) (a)

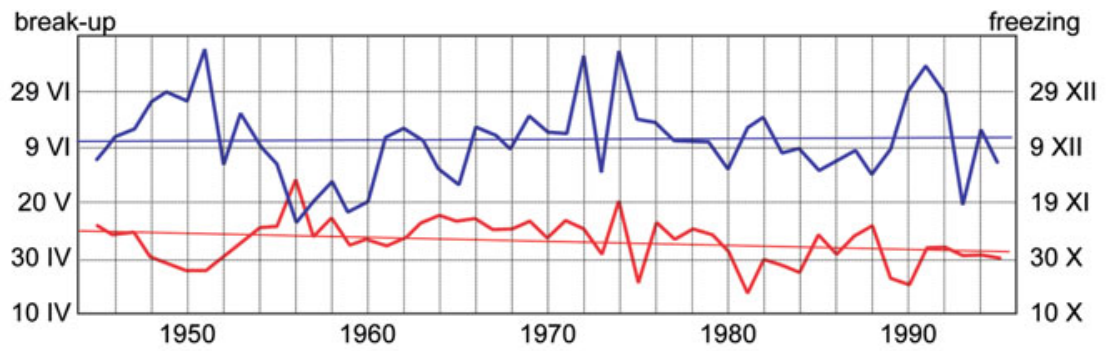

(b)

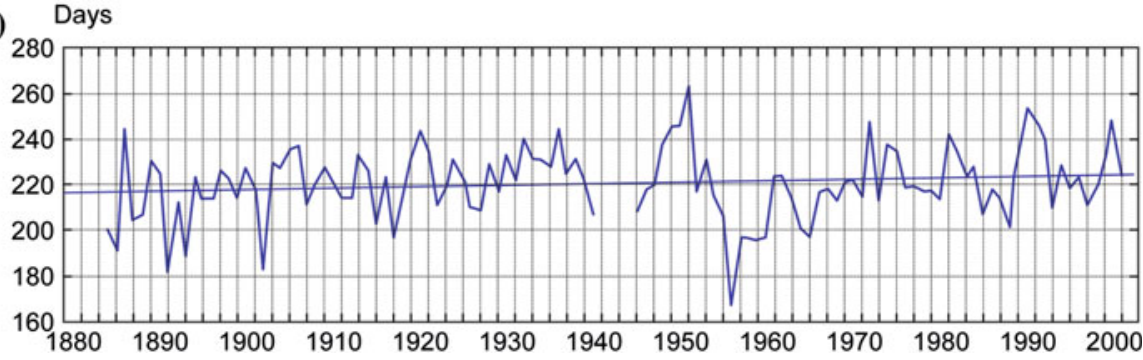


Fig. 5.21 Date of a freeze-up and $\mathbf{b}$ break-up on a large lake (Onego), a middle size lake (Vodlozero) and a small lake (Tulmozero) for 1950-2009. The linear trends for 1950-2009 and 1990-2009 are shown by the solid and dashed line, respectively (Efremova and Palshin 2011) (a)

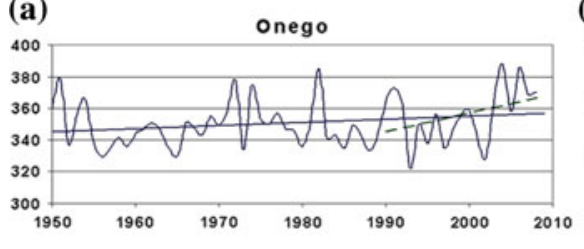

(b)
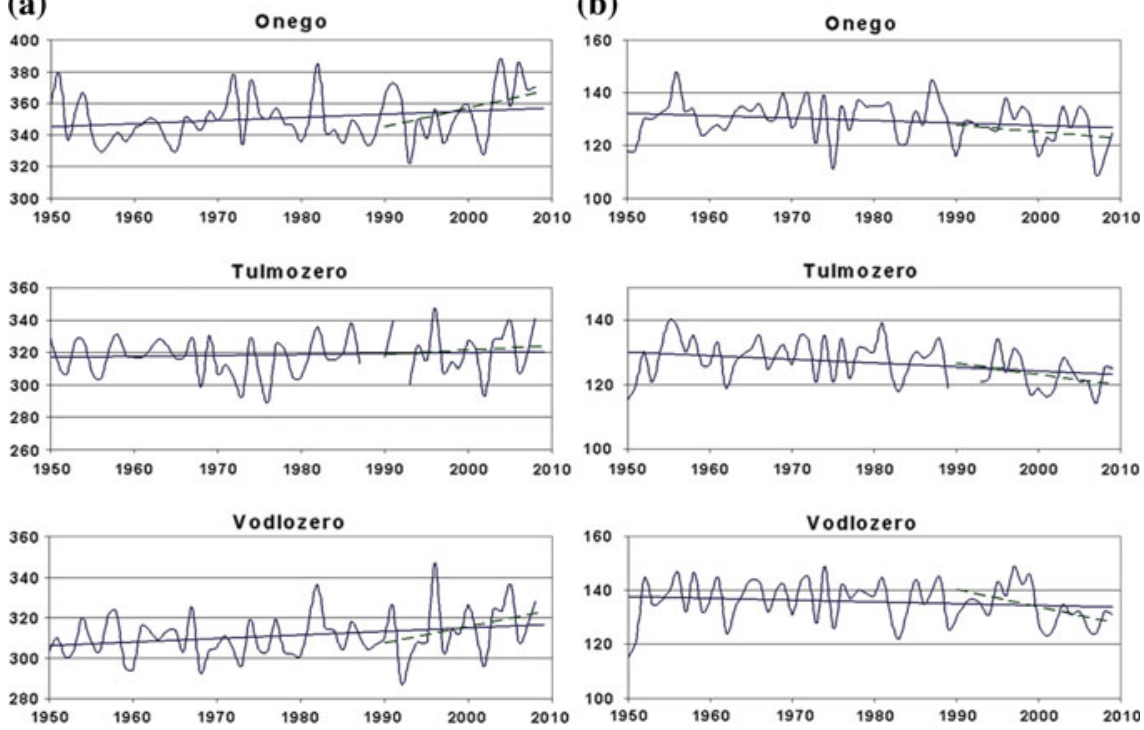

date of freeze-up and ice break-up on three lakes of different sizes in Russia (Efremova and Palshin 2011).

\subsection{Conclusion}

The recently published literature and data collected by national authorities on river hydrology of the Baltic Sea basin support and are generally in line with the findings reported in the first assessment of climate change in the Baltic Sea basin (BACC Author Team 2008). No statistically significant trends have been detected in annual river discharge in the Baltic Sea basin as a whole, and temperature change seems to explain change in run-off better than does precipitation. Winter discharge has increased due to higher temperatures and subsequent snowmelt, while spring discharge has decreased as less snow is present. Regional variations occur in response to climate (temperature, precipitation) and discharge cyclicity. Later start dates for ice formation on rivers and earlier ice break-up dates have resulted in shorter ice duration on rivers in the Baltic Sea basin.

Open Access This chapter is distributed under the terms of the Creative Commons Attribution Noncommercial License, which permits any noncommercial use, distribution, and reproduction in any medium, provided the original author(s) and source are credited.

\section{References}

Alexandersson H (2002) Temperatur och nederbörd i Sverige 18602001. SMHI Rapporter Meteorologi 104

Apsīte E, Bakute A, Rudlapa I (2009) Changes of total annual runoff distribution, high and low discharges in Latvian rivers. P Latvian Acad Sci B 63:279-286
Apsīte E, Rudlapa I, Pallo I, Elferts D (2013) Changes in Latvian discharge regime at the turn of century. Hydrol Res 44:554-569

BACC Author Team (2008) Assessment of Climate Change for the Baltic Sea Basin. Regional Climate Studies, Springer Verlag, Berlin, Heidelberg

Bergström S (1976) Development and application of a conceptual runoff model for Scandinavian catchments. SMHI Report RHO 7

Bergström S (1992) The HBV model - its structure and applications. SMHI Report RH 4

Bordi I, Fraedrich K, Sutera A (2009) Observed drought and wetness trends in Europe: an update. Hydrol Earth Syst Sci 13:1519-1530

Bukantis A, Gulbinas Z, Kazakevičius S (2001) Klimato svyravimu poveikis fiziniams geografiniams procesams Lietuvoje, Vilnius

Efremova T, Palshin N (2011) Data of ice features on water bodies of North West Russia. Meteorol Hydrol 8:89-98

EMHI (2011) Estonian Meteorological and Hydrological Institute. www.emhi.ee/?ide $=9,1476$

Gailiušis B, Kriaučiūnienė J, Jakimavičius D, Šarauskienė D (2011) The variability of long-term runoff series in the Baltic Sea drainage basin. Baltica 24:45-54

Glen G (ed) (2010) The Impact of Climate Change on European Lakes. Springer

Graham LP, Olsson J, Kjellström E, Rosberg J, Hellström S-S, Berndtsson R (2009) Simulating river flow to the Baltic Sea from climate simulations over the past millennium. Boreal Environ Res 14:173-182

Gronskaja TP (2008) Water resources of lakes. In: Shiklomanov I (ed), Water Resources of Russia and their Use, St Petersburg, p 166-175 [in Russian]

Filatov N, Nazarova L, Semenov A, Bogdan M, Ancifirova A, Georgiev A, Ojigina V (2012). Climate changes and variability of European north part of Russia and their influence on water objects. J Arctic Ecol Econ 2:80-94 [in Russian].

Hagen E, Feistel R (2005). Climatic turning points and regime shifts in the Baltic Sea region: the Baltic winter index (WIBIX) 1659-2002. Boreal Environ Res 10:211-224

Hannerz F, Destouni G (2006) Characterization of the Baltic Sea drainage basin and its unmonitored catchments. Ambio 35:214-219

Hansson D, Eriksson C, Omstedt A, Chen D (2011) Reconstruction of river runoff to the Baltic Sea, AD 1500-1995. Int J Climatol 31:696-703 
Hellström S, Lindström G (2008) Regional analys av klimat, vattentillgång och höga flöden. SMHI Rapport Hydrologi 110

Hisdal H, Holmqvist E, Hyvärinen V, Jónsson P, Kuusisto E, Larsen SE, Lindström G, Ovesen NB, Roald LA (2003) Long time series a review of Nordic studies. Climate, Water and Energy Projects 2, Reykjavik, Iceland

Hisdal H, Holmqvist E, Jónsdóttir JF, Jónsson P, Kuusisto E, Lindström G, Roald LA (2010) Has streamflow changed in the Nordic countries? Norwegian Water Resources and Energy Directorate, No 1

Karetnikov S, Naumenko M (2008) Recent trends in Lake Ladoga ice cover. Hydrobiologia 599:41-48

Kḷaviņš M, Rodinov V (2008) Long-term changes of river discharge regime in Latvia. Nord Hydrol 39:133-141

Kḷaviņš M, Briede A, Rodinov V (2007) Ice regime of river in Latvia in relation to climatic variability and North Atlantic Oscillation. In: Kļavinš̌ M (ed) Climate Change in Latvia, p 58-72

Kļaviņš M, Rodinov V, Timukhin A, Kokorīte I (2008) Patterns of river discharge: long-term changes in Latvia and the Baltic region. Baltica 21:41-49

Kḷaviņš M, Briede A, Rodinov V (2009) Long term changes in ice and discharge regime of rivers in the Baltic region in relation to climatic variability. Climatic Change 95:485-498

Korhonen J (2007) Discharge and water level variations in lakes and rivers in Finland. Suomen ympäristö (The Finnish Environment) 45, (In Finnish with English abstract)

Korhonen J, Kuusisto E (2010) Long-term changes in the discharge regime in Finland. Hydrol Res 41:253-268

Kriaučiūnienė J, Kovalenkovienė M, Meilutyte-Barauskiene D (2007) Changes of the low flow in Lithuanian rivers. Environ Res Eng Manag 42:5-12

Kriaučiūnienė J, Meilutytė-Barauskienė D, Kovalenkovienė M (2008) Regional series of temperature, precipitation and runoff for Lithuania. In: Proceedings of the XXV Nordic Hydrological Conference, 11-13 August 2008, Reykjavik, Iceland. NHP 50:638-645

Kriaučiūnienė J, Meilutyte-Barauskiene D, Reihan A, Koltsova T, Lizuma L, Šarauskiene D (2012) Variability of regional series of temperature, precipitation and river discharge in the Baltic States . Boreal Environ Res 17:150-162
Legutke S, Voss R (1999). The Hamburg atmosphere-ocean coupled model ECHO-G. German Climate Computer Center, Tech Rep 18

Lindström G (2011) Klimat, vattentillgång och högaflöden i Sverige 1860-2010. Elforsk rapport 11:73

Lindström G, Alexandersson H (2004) Recent mild and wet years in relation to long observation records and climate change in Sweden. Ambio 33:183-186

Meilutytė-Barauskienė D, Kriaučiūnienė J, Kovalenkovienė M (2010) Impact of climate change on runoff of the Lithuanian rivers. Modern climate change models, statistical methods and hydrological modelling. Lambert Academic Publishing

Reihan A, Koltsova T, Kriaučiūnienè J, Lizuma L, MeilutytèBarauskiene D (2007) Changes in water discharges of the Baltic states rivers in the 20th century and its relation to climate change. Nord Hydrol 38:401-412

Salo Y, Nazarova L (2011) Many years variability of ice regime of Lake Onego under regional climate instability. T Russian Geogr Soc 143:50-54

Samuelsson P, Jones CG, Willén U, Ullerstig A, Gollvik S, Hansson U, Jansson C, Kjellström E, Nikulin G, Wyser K (2010). The Rossby Centre Regional Climate model RCA3: model description and performance. Tellus A 63:4-23

Šarauskienė D, Jurgelènaite A (2008) Impact of climate change on river ice phenology in Lithuania. Environ Res Eng Manag 46:13-22

Shiklomanov I (ed) (2008) Water Resources of Russia and their Use. St Petersburg [in Russian]

Stahl K, Hisdal H, Hannaford J, Tallaksen LM, van Lanen HAJ, Sauquet E, Demuth S, Fendekova M, Jódar J (2010) Streamflow trends in Europe: evidence from a dataset of near-natural catchments. Hydrol Earth Syst Sci 14:2367-2382

Stonevicius E, Stankunavicius G, Kilkus K (2008) Ice regime dynamics in the Nemunas River, Lithuania. Clim Res 36:17-28

Veijalainen N, Lotsari E, Alho P, Vehviläinen B, Käyhkö J (2010) Changes in floods in Finland due to climate change: General assessment on national scale. J Hydrol 391:333-350

Wilson D, Hisdal H, Lawrence D (2010) Has streamflow changed in the Nordic countries? Recent trends and comparisons to hydrological projections. J Hydrol 394:334-346 